\title{
Fish-based groups for ecological assessment in rivers: the importance of environmental drivers on taxonomic and functional traits of fish assemblages
}

\author{
P. Matono ${ }^{(1,2)^{\star}}$, J.M. Bernardo(1) M.T. Ferreira $^{(3)}$, N. Formigo ${ }^{(4)}$, \\ P. Raposo de Almeida ${ }^{(5)}$, R. Cortes ${ }^{(6)}, M$. Ilhéu ${ }^{(1,2)}$ \\ Received October 25, 2011 \\ Revised March 18, 2012 \\ Accepted March 21, 2012
}

\section{ABSTRACT}

Key-words: freshwater fish, waterframework directive, river-types, ecological quality assessment, Portugal
The use of river-types is of practical value, serving as groups for which assessment procedures can be developed and applied. An abiotic typology was set by the Portuguese Water Agency, mainly based on 6 major morphoclimatic regions. However, to be biologically meaningful, this typology should fit the distribution patterns of the biological quality elements communities proposed in Water Framework Directive under the lowest possible human pressure. This study aimed to identify and characterize fish-based geographical groups for continental Portugal and their environmental and geographical discriptors, using taxonomic and functional traits. Sampling took place between 2004 and 2006 during Spring. Fish fauna from 155 reference sites was analysed using a multivariate approach. Cluster Analysis on fish composition identified 10 fish-groups, expressing a clear correspondence to the river basin level, due to the restrict basin distribution of many species. Groups showed a wider aggregation in 4 regions with a larger geographical correspondence, statistically supported by Similarity Analysis, both on fish composition and mostly on fish metrics/guilds. Principal Components Analysis revealed major environmental drivers associated to fish-groups and fish-regions. Fish-groups were hierarchically grouped over major and local regions, expressing a large-scale response to a North-South environmental gradient defined by temperature, precipitation, mineralization and altitude, and a regional scale response mainly to drainage area and flow discharge. From North to South, fish-regions were related to the morphoclimatic regions. Results contributed to reduce redundance in abiotic river-types and set the final typology for Portuguese rivers, constituting a fundamental tool for planning and managing water resources.

(1) Department of Landscape, Environment and Planning, School of Sciences and Technology, University of Évora, Rua Romão Ramalho 59, 7000-671 Évora, Portugal

(2) Institute of Agrarian and Environmental Mediterranean Sciences (ICAAM), University of Évora, Núcleo da Mitra, apartado 94, 7002-774 Évora, Portugal

(3) Forestry Department, Superior Institute of Agronomy, Technical University of Lisbon, Tapada da Ajuda, 1349-017 Lisboa, Portugal

(4) Department of Zoology and Antropology, Faculty of Sciences, Porto University, 4099-002 Porto, Portugal.

(5) Department of Biology, School of Sciences and Technology, University of Évora, Largo dos Colegiais 2, 7000 Évora, Portugal

(6) Forestry Department, University of Trás-os-Montes e Alto Douro, 5000-911 Vila Real, Portugal

*Corresponding author: pmatono@uevora.pt 


\section{RÉSUMÉ}

Groupes ichtyologiques pour l'évaluation écologique des rivières : importance des facteurs environnementaux sur la taxonomie et les caractéristiques fonctionnelles des peuplements de poissons

Mots-clés : poissons d'eau douce, directive cadre sur l'eau, rivières types, facteurs environnementaux, évaluation de la qualité écologique
L'utilisation de rivière-types est un moyen pratique, fournissant des groupes pour lesquels des procédures d'évaluation peuvent être développées et appliquées. Une typologie abiotique a été fixée par l'Agence de l'Eau Portugaise, principalement basée sur 6 principales régions morphoclimatiques. Toutefois, pour être biologiquement significative, cette typologie devrait correspondre aux schémas de distribution des communautés, éléments de qualité biologique, proposés dans la directive cadre sur l'eau sous la pression anthropique la plus basse possible. Cette étude visait à identifier et à caractériser des groupes géographiques reposant sur les communautés ichtyologiques pour le Portugal continental et leurs descripteurs environnementaux et géographiques, à l'aide de traits taxonomiques et fonctionnels. L'échantillonnage a eu lieu entre 2004 et 2006 au cours du printemps. La faune de poissons provenant de 155 sites de référence a été analysée en utilisant une approche multivariée. L'analyse de clusters sur la composition en poissons a identifié 10 groupes ichtyologiques, exprimant une correspondance claire à l'échelle du bassin versant, en raison de la distribution limitée à un bassin de nombreuses espèces. Les groupes ont montré une plus large agrégation dans 4 régions avec une plus grande correspondance géographique, confirmée statistiquement par l'analyse de similarité, à la fois sur la composition en poisson et surtout sur les métriques ichtyologiques ou les guildes. L'analyse en Composantes Principales a révélé les principaux facteurs environnementaux associés aux groupes et régions ichtyologiques. Les groupes ichtyologiques ont été regroupés hiérarchiquement sur des régions locales et plus grandes, exprimant une réponse à grande échelle à un gradient Nord-Sud de l'environnement défini par la température, les précipitations, la minéralisation et l'altitude, et une réponse à l'échelle régionale principalement à l'aire de drainage et au débit. Du Nord au Sud, les régions ichtyologiques étaient liées aux zones morphoclimatiques. Les résultats contribuent à réduire la redondance dans les types abiotiques de rivières et définissent la typologie finale pour les rivières portugaises, constituant un outil fondamental pour la planification et la gestion des ressources en eau.

\section{INTRODUCTION}

Running waters belong to the most intensively used and altered ecosystems of the world (Saunders et al., 2002; Clavero et al., 2004; Levin et al., 2009). In Europe, about 80\% of rivers are affected by water pollution, water removal for hydropower and irrigation, structural alterations and the impact of dams (Schinegger et al., 2011).

Over the last few decades tremendous efforts have been undertaken to develop management strategies to improve the ecological status of these ecosystems. The European Union has taken a new course in water policy towards an integrated management of water bodies by enacting a new legislation, the Water Framework Directive (WFD) (European Commission, 2000). The WFD requires Member States of the European Union to assess, monitor and, where necessary, improve the ecological quality status of surface waters, seeking to achieve at least 'good ecological status' by 2015 . This landmark piece of environmental legislation incorporates for the first time the importance of the aquatic biota to determine the quality of fresh and marine waters (Sweeting, 2001; Logan and Furse, 2002), and the importance of biogeographical drivers of species distribution patterns (e.g. Illies, 1978).

According to WFD, the definition of a typology to classify rivers and streams is the first and fundamental step for the ecological assessment. Differences between climate, hydrology, geomorphology, geology, soil composition, land use and vegetation make comparison of communities in running waters difficult. Thus, a typological approach is a way to stratify the 
spatial variability in stream and river monitoring and assessment, i.e. allowing comparing groups of streams, and constituting classes for which assessment procedures can be developed and applied. In Portugal, no attempts to derive a national river typology were made before the implementation of the WFD.

The establishment of a river typology is supported by a set of reference sites, i.e., in the absence of anthropogenic disturbance, as it is assumed that biological communities are optimal developed at undisturbed or reference conditions (Karr and Chu, 1999). Reference conditions are best described at the scale of a river-type (Nijboer et al., 2004) and the comparison of conditions at a current site with those of a reference site belonging to the same stream-type allows an ecological quality evaluation. In short, a typology should be simple, intuitively understandable, with a minimum number of river types, whilst reducing natural variation of reference conditions within river-types (Dodkins et al., 2005).

Reference sites should be viewed as the least disturbed sites within a river-type, rather than actual pristine conditions, as they rarely exist in most European countries. Although humaninduced disturbance occur among all river-types, some areas exhibit higher degradation status. Overall, river-types with higher human density tend to present higher degradation conditions and therefore reference sites can be quite rare (Matono, 2012). The least disturbed river-types are usually located in high altitude regions (and small drainage basins), frequently in isolated areas with difficult human access, far from the main human pathways (Chaves et al., 2006; Schinegger et al., 2011).

The WFD defined abiotic descriptors for classifying streams and rivers into types (Annex II, Section 1 of the WFD) according to two alternative systems: (i) "system A", the fixed typology, is defined by ecoregions (according to Illies, 1978), based on the catchment area, catchment geology and altitude; (ii) "system B" uses five obligatory factors (latitude, longitude, altitude, geology and drainage area of the basin), and an additional group of optional factors. The Portuguese Water Agency (INAG) chose system B, as it expressed better the ecological heterogeneity of Portuguese rivers (Alves et al., 2004; INAG, 2008a). Therefore, besides the obligatory factors, six more optional factors are also considered: slope, mean annual precipitation, coefficient of variation of precipitation, mean annual discharge, mean annual temperature and mean annual temperature range. These optional factors together with altitude, latitude and longitude allowed identifying 6 major morphoclimatic regions in continental Portugal as the main base for the definition of the abiotic typology (Alves et al., 2004; INAG, 2008a). Further interception of these regions with geological and drainage area classes made possible the establishment of the final abiotic river-types (Alves et al., 2004; INAG, 2008a).

To be biologically meaningful, the abiotic river-types should fit the distribution patterns of the biological quality elements, namely fish fauna, under the lowest possible human pressure. Though in the past fish fauna deserved much less attention than other biological groups regarding environmental monitoring, it presents several important attributes as a bio-indicator (Barbour et al., 1999).

Due to zoogeographical traits, Iberian fish fauna is very rich in endemisms, many restricted to particular basins. Native species richness per site is generally low (Griffiths, 2006; Reyjold et al., 2007) and had undergone a steep decline during the last decades (Doadrio, 2002; Cabral et al., 2005; Smith and Darwall, 2006; Ribeiro et al., 2009). Moreover fish assemblages from Iberain Peninsula may present a high variability both at seasonal and inter-annual scale determined by the influence of Mediterranean climate (Gasith and Resh, 1999; Bernardo et al., 2003; Ilhéu, 2004). All these aspects cause considerable difficulties in the development of tools to assess the ecological status of Mediterranean climate streams, namely regarding fish fauna.

This study aimed to identify environmental and geographical discriptors of fish assemblages and characterize fish-based geographical groups for continental Portugal, using taxonomic and functional traits. Furthermore it should contribute to adjust the abiotic types limits and, if possible, to reduce their number, while improving its consistency. 
The complementary use of fish composition, structural and functional fish metrics constitutes an added value in the approach of defining fish-based groups to subsequently derive rivertypes. Indeed, the analysis of functional organization of fish assemblages allows characterizing different aspects of the community structure other than taxonomic organization (Hoeinghaus et al., 2007; Higgins and Strauss, 2008) and permit comparisons among broad geographic regions even when communities present different taxa (Simberloff and Dayan, 1991). In the Iberian Peninsula this approach will contribute to avoid problems related to spatially restricted endemisms. Moreover, it provides a means of testing theoretical expectations of changes in species traits along environmental gradients, such as those generated from habitat templates (Southwood, 1977), the river continuum concept (Vannote et al., 1980), and landscape filters (Poff, 1997).

\section{MATERIALS AND METHODS}

\section{> STUDY AREA}

Continental Portugal is located in the SW extreme of the Iberian Peninsula, covering an area of nearly $90000 \mathrm{~km}^{2}$. The geography is dominated by a mixture of Atlantic (in the northern regions) and Mediterranean (in the southern regions) influences.

The climate is Mediterranean, although the influence of factors such as topography and proximity to the Atlantic Ocean cause significant climatic contrasts in a country of a small size as Portugal (Ribeiro, 2011). The general conditions of the atmospheric circulation cause a decrease in precipitation from North to South and from West (littoral) to the East (interior), enhanced by topographical asymmetry. The temperature shows an opposite pattern, increasing from North to South (http://www.igeo.pt/atlas/).

Regarding the relief, the territory is very unequal. The South is a lowland region with few low altitude mountains. To the North of river Tagus the land presents high spatial heterogeneity, including $95 \%$ of the areas above $400 \mathrm{~m}$ and all the elevations higher than $1000 \mathrm{~m}$. The altitude causes a decrease in temperature and an increase in rainfall (http://www.igeo.pt/atlas/).

The characteristics of the hydrographical network are related to the nature of the rocks, tectonic accidents and climate of the areas traversed. Rivers flow regimes reflect the rainfall variations and are among the most irregular of Europe.

While the South is quite homogeneous, mostly represented by lowland streams and river (flat, less rainy, with long hot dry summers), the North presents a much more complex climatic and geomorphological patchiness, with higher average altitudes, higher annual precipitation, and milder summers in general. Due to these features, most rivers are permanent in the North and intermittent in the South (http://geo.snirh.pt/AtlasAgua; Bernardo and Alves, 1999; INAG, 2008a).

Considering the 6 major morphoclimatic regions identified for Portugal (Alves et al., 2004; INAG, 2008a), four are located at the North of river Tagus (regions 3, 4, 5 and 6) and two at the South (regions 1 and 2) (Figure 1). In the South, region 3 is present in small areas with higher altitude and humidity. The numbering of the regions reflects an environmental gradient, with regions 1 and 6 presenting more extreme characteristics. Region 1 is the most arid one, showing higher temperature and less precipitation. Region 6 is located in northern Portugal and includes regions with relatively high altitude and rainfall. The remaining regions form a gradient between these extremes.

\section{$>$ SAMPLING}

Sampling was carried out during spring between 2004 and 2006 in 155 undisturbed sites in the main Portuguese river basins (Figure 2). For the selection of these undisturbed sites, a preliminary pressure screening using GIS and information on pollution loads was followed. The final selection was based on the human disturbance level, regarding ten semi-quantitative 


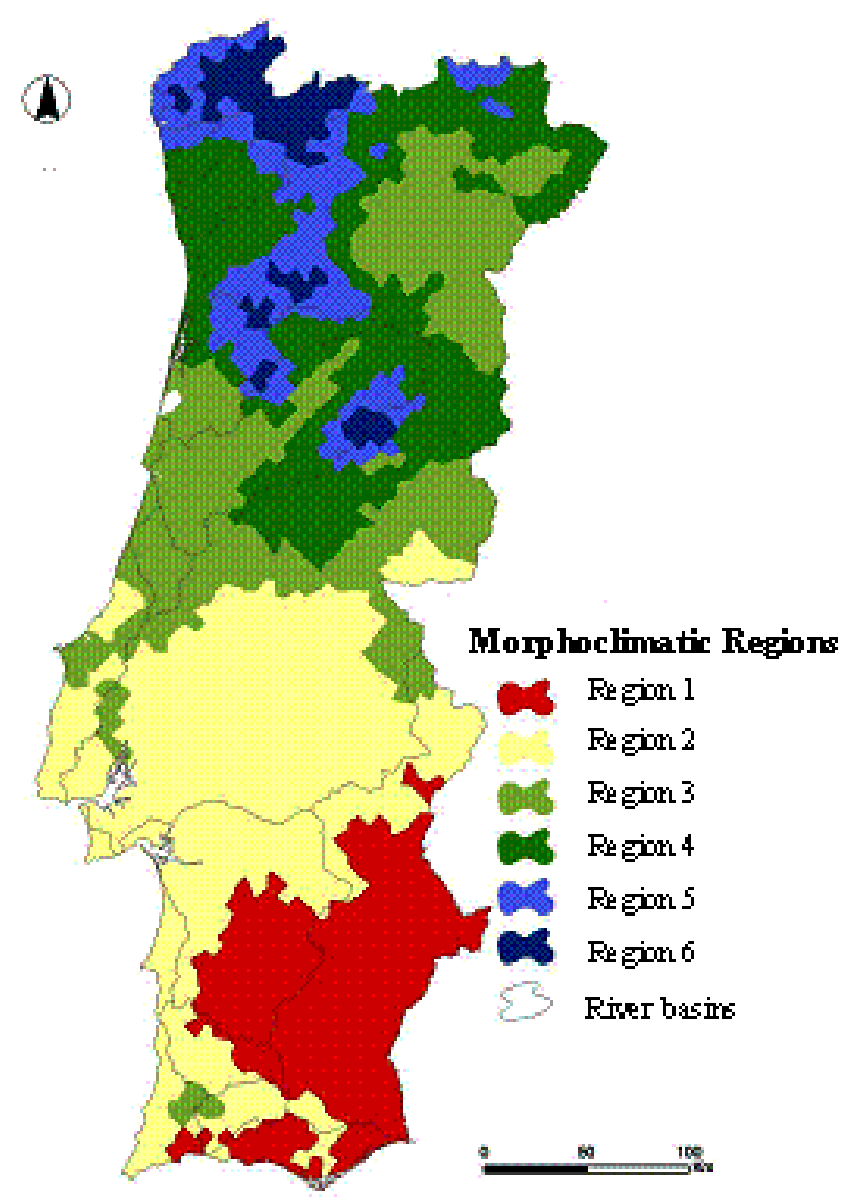

\section{Figure 1}

Major morphoclimatic regions identified for continental Portugal (Alves et al., 2004; INAG, 2008a).

variables assessed at each site (formerly developed within EU-project FAME, 2004; available at http://fame.boku.ac.at): land use, urban area, riparian vegetation, longitudinal connectivity of the river segment, sediment load, hydrological regime, morphological condition, presence of artificial lentic water bodies, toxicological and acidification levels, and nutrient/organic load. Each variable was scored from 1 (minimum disturbance) to 5 (maximum disturbance) (Appendix 1) and only sites with scores 1 and/or 2 and only one variable with a 3 were considered as undisturbed or least disturbed (references) (following CIS-WFD, 2003).

Several physicochemical variables complemented and supported the evaluation of human pressure in each site, after laboratory measurements and analyses according to the Standard Methods for the Examination of Water and Wastewater (Clesceri et al., 1998): biological oxygen demand $-\mathrm{BOD}_{5}\left(\mathrm{mg} \cdot \mathrm{L}^{-1}\right)$, chemical oxygen demand - COD $\left(\mathrm{mg} \cdot \mathrm{L}^{-1}\right)$, oxidability

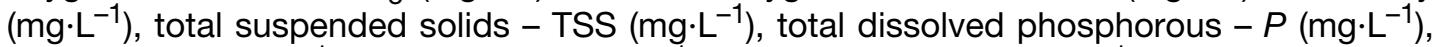
nitrite $-\mathrm{NO}_{2^{-}}\left(\mathrm{mg} \cdot \mathrm{L}^{-1}\right)$, nitrate $-\mathrm{NO}_{3^{-}}\left(\mathrm{mg} \cdot \mathrm{L}^{-1}\right)$, ammonium $-\mathrm{NH}_{4+}\left(\mathrm{mg} \cdot \mathrm{L}^{-1}\right)$ and total dissolved nitrogen $-\mathrm{N}\left(\mathrm{mg} \cdot \mathrm{L}^{-1}\right)$.

Fish were collected by electrofishing according to the WFD compliant sampling protocol (INAG, 2008b), which follows the CEN standards (CEN, 2003). All collected individuals were measured, identified to the species level and immediately returned to the river.

Landscape and regional variables were obtained from digital cartography with free internet access and included latitude, longitude, mineralization level, drainage area of the basin $\left(\mathrm{km}^{2}\right)$, distance from source $(\mathrm{km})$, altitude $(\mathrm{m})$, slope $(\%)$, mean annual discharge $(\mathrm{mm})$, mean annual 


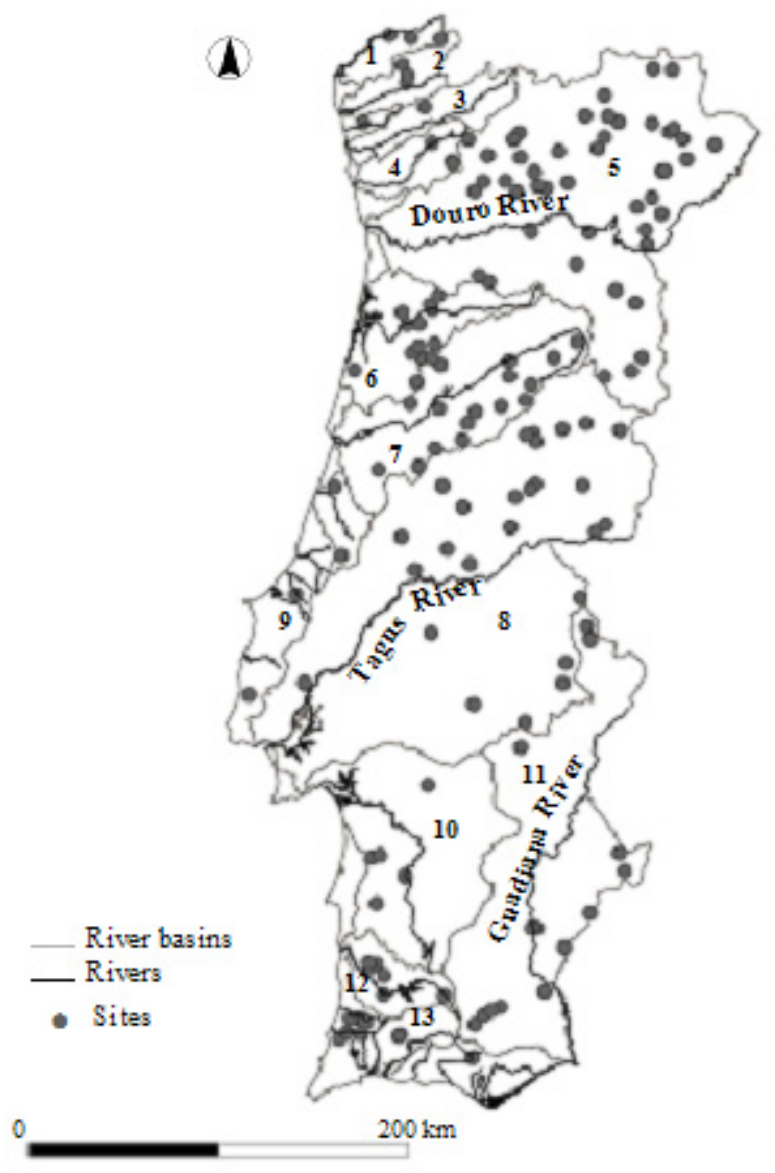

\section{Figure 2}

Map of the sampled sites in the principal continental Portuguese river basins: 1-Minho, 2-Lima, 3-Cávado, 4-Ave, 5-Douro, 6-Vouga, 7-Mondego, 8-Tagus, 9-West streams, 10-Sado, 11Guadiana, 12-Mira, 13-Algarve streams.

air temperature $\left({ }^{\circ} \mathrm{C}\right)$, mean temperature range, mean annual precipitation $(\mathrm{mm})$ and coefficient of variation of precipitation. Rainfall, temperature and flow variables were described from 30-year data series.

Local variables were assessed during the sampling procedure: water temperature $\left({ }^{\circ} \mathrm{C}\right)$, conductivity $\left(\mu \mathrm{S} \cdot \mathrm{cm}^{-1}\right), \mathrm{pH}$, dissolved oxygen $\left(\mathrm{mg} \cdot \mathrm{L}^{-1}\right)$, mean stream wetted width $(\mathrm{m})$, maximum and mean water depth $(\mathrm{m})$, mean current velocity $\left(\mathrm{m} \cdot \mathrm{s}^{-1}\right)$, dominant substrate class (adapted from Wentworth scale (Giller and Malmqvist, 1998): 1-mud and sand; 2-gravel; 3-pebble; 4-cobble; 5-boulders; 6-boulders larger than $50 \mathrm{~cm}$ ), riparian vegetation (\%), shadow (\%) and proportion of different habitat types (pool, run, riffle).

\section{> DATA ANALYSIS}

Captures were quantified as density (ind. $/ 100 \mathrm{~m}^{2}$ ). Besides taxonomic data, the community structure was also considered: fish density (number of fish/100 $\mathrm{m}^{2}$ ), number of species $(\mathrm{S})$, species diversity (Shannon-Wiener Index $-\mathrm{H}$ ), relative abundance of potamodromous individuals, habitat guilds (proportion of rheophilic, limnophilic, eurytopic, benthic and water column individuals), trophic guilds (proportion of omnivorous and insectivorous individuals) and reproductive guilds (proportion of lithophilic and phytophilic individuals) (Table I). The 


\section{Table I}

Eclogical classification of fish species (according to FAME, 2004; Ilhéu, 2004; Cabral et al. 2005; Holzer, 2008; Magalhães et al., 2008): B (benthic), WC (water column), EUR (eurytopic), RF (rheophilic), LIM (limnophilic), PHY (phythophilic), LIT (lithophilic), OMNI (omnivorous), INSV (insectivorous), POTAD (potamodromous), DIAD (diadromous), NAT (native), END (endemic), EX (exotic/non-native).

\begin{tabular}{|c|c|c|}
\hline Species & Common name & Classification \\
\hline Anaecypris hispanica (Steindachner, 1866) & $\begin{array}{l}\text { Spanish Minnow } \\
\text { Carp }\end{array}$ & WC; LIM; END \\
\hline Anguilla anguilla (Linnaeus) & Eel & B; EUR; DIAD; NAT \\
\hline Barbus spp. juveniles & juvenile Barbels & WC; RF; LIT; OMNI; POTAD; END \\
\hline Barbus bocagei (Steindachner, 1864) & Common Barbel & B; LIM; LIT; OMNI; POTAD; END \\
\hline Barbus comizo (Steindachner, 1864) & Iberian Gudgeon & WC; LIM; LIT; OMNI; POTAD; END \\
\hline Barbus microcephalus (Almaça, 1967) & Small-head Barbel & B; LIM; LIT; OMNI; POTAD; END \\
\hline Barbus sclateri (Gunther, 1868) & South Barbel & B; LIM; LIT; OMNI; POTAD; END \\
\hline Carassius auratus (Linnaeus) & Goldfish & B; LIM; PHY; OMNI; EX \\
\hline Cobitis calderoni (Bacescu, 1962) & Stone Loach & B; RF; LIT; INSV; END \\
\hline Cobitis paludica (de Buen, 1930) & South Stone Loach & B; LIM; INSV; END \\
\hline Cyprinus carpio (Linnaeus) & Common Carp & B; LIM; PHY; OMNI; EX \\
\hline Achondrostoma arcasii (Steindachner,1866) & Iberian Roach & WC; RF; PHY; OMNI; END \\
\hline $\begin{array}{l}\text { Achondrostoma oligolepis (Robalo et al., } \\
\text { 2005) }\end{array}$ & Portuguese Roach & WC; LIM; PHY; INSV; END \\
\hline $\begin{array}{l}\text { Iberochondrostoma lemmingii } \\
\text { (Steindachner, 1866) }\end{array}$ & $\begin{array}{l}\text { Arched-mouth } \\
\text { Nase }\end{array}$ & WC; LIM; LIT; OMNI; END \\
\hline $\begin{array}{l}\text { Iberochondrostoma Iusitanicum } \\
\text { (Collares-Pereira, 1980) }\end{array}$ & Portuguese Nase & WC; LIM; LIT; OMNI; END \\
\hline $\begin{array}{l}\text { Pseudochondrostoma polylepis } \\
\text { (Steindachner, 1865) }\end{array}$ & Iberian Nase & B; RF; LIT; OMNI; POTAD; END \\
\hline $\begin{array}{l}\text { Pseudochondrostoma duriense } \\
\text { (Coelho, 1985) }\end{array}$ & Douro Nase & B; RF; LIT; OMNI; POTAD; END \\
\hline $\begin{array}{l}\text { Pseudochondrostoma willkommii } \\
\text { (Steindachner, 1866) }\end{array}$ & Guadiana Nase & B; RF; LIT; OMNI; POTAD; END \\
\hline Gambusia holbrooki (Girard, 1859) & Mosquitofish & WC; LIM; INSV; EX \\
\hline Gasterosteus gymnurus (Cuvier, 1829) & $\begin{array}{l}\text { Three-Spined } \\
\text { Stickleback }\end{array}$ & WC; EUR; OMNI; NAT \\
\hline Gobio lozanoi (Doadrio and Madeira, 2004) & Gudgeon & B; RF; INSV; EX \\
\hline Herichtys facetum (Jenyns, 1842) & Chamaleon Cichlid & WC; LIM; OMNI; EX \\
\hline Lampetra planeri (Bloch, 1784) & Brook Lamprey & B; RF; LIT; OMNI; POTAD; NAT \\
\hline Lepomis gibbosus (Linnaeus) & Pumpkinseed & WC; LIM; INSV; EX \\
\hline Micropterus salmoides (Lacépède, 1802) & Largemouth Bass & WC; LIM; PHY; EX \\
\hline Petromyzon marinus (Linnaeus) & Sea Lamprey & B; RF; LIT; DIAD; NAT \\
\hline Salaria fluviatilis (Asso, 1801) & Freshwater blenny & B; RF; LIT; INSV; NAT \\
\hline Salmo trutta (Linnaeus) & Brown Trout & WC; RF; LIT; INSV; NAT \\
\hline Squalius alburnoides (Steindachner, 1866) & Roach & WC; EUR; LIT; INSV; END \\
\hline Squalius aradensis (Coelho et al., 1998) & Arade Chub & WC; EUR; LIT; INSV; END \\
\hline Squalius carolitertii (Doadrio, 1988) & North Chub & WC; EUR; LIT; INSV; END \\
\hline Squalius pyrenaicus (Günther, 1868) & Iberian Chub & WC; EUR; LIT; INSV; END \\
\hline Squalius torgalensis (Coelho et al., 1998) & Torgal Chub & WC; EUR; LIT; INSV; END \\
\hline
\end{tabular}


species were assigned and classified into guilds according to published literature (FAME, 2004; Ilhéu, 2004; Cabral et al. 2005; Holzer, 2008; Magalhães et al., 2008) and expert judgement on their life history traits, when necessary.

Hierarchical Cluster Analysis using Euclidean distance and Ward's method was used to identify groups of sites based on fish composition (density).

Similarity Analysis (ANOSIM) for 1-way layout (Clarke and Warwick, 1994) was performed on fish composition and metrics/guilds to determine if there were significant differences between fish-groups. The test value $(R)$ varies between 1 , when samples are completely separated, and 0 if there is no separation on the averages between and among samples. As a rule of thumb, Clarke and Gorley (2001) consider pairs of samples which display an $R \geq 0.75$ as being well separated from each other, those with $0.5 \leq R \leq 0.75$ as overlapping but still clearly different and those with $R \leq 0.5$ as barely separable at all.

Reference sites include undisturbed (all human pressure variables scored with 1 and/or 2) and least disturbed sites (one human pressure variable scored with 3 and the remaining ones with 1 and/or 2), when these were the only available ones for sampling. As such, Similarity Analysis (ANOSIM) was also performed on fish assemblages composition (density) between undisturbed and least disturbed sites in order to understand if the influence of some anthropogenic pressure (score 3 in one of the variables) in least disturbed sites could result in significant differences in the occurrence of some species, thus hampering the consistency of the reference sites.

Environmental drivers of fish-groups were explored with Principal Components Analysis $(P C A)$, based on large, regional and local scale variables of sampling sites. Most intercorrelated variables (Spearman's rank correlations $|r|>0.8 ; P<0.05$ ) were excluded.

Indicator Species Analysis (Dufréne and Legendre, 1977) allowed recognizing species that identified each group.

For statistical analysis data were transformed to improve normality: percentages were arcsin [sqrt $(x)]$ and linear measurements were log $(x+1)$ (Legendre and Legendre, 1998). Species with very low frequency of occurrence (smaller than 0.02 ) were excluded from the analysis.

Data analysis was performed with statistical programs Pc-ord 4, Primer 6 and Canoco 4.5. For geographical delimitation of fish-groups/regions the image processing program Gimp 2.6 was used.

\section{RESULTS}

\section{> FISH-BASED GEOGRAPHICAL GROUPS}

A total of 32 fish species from 10 families were captured, including freshwater and 2 diadromous species. Although 7 non-native species were captured, freshwater native species $(N=23)$ represented $72 \%$ of the total sampled species and $98 \%$ of the fish density in the captures.

No fish was captured in $13 \%$ of the sampling sites. These sites were mainly located in small drainage areas (smaller than $30 \mathrm{~km}^{2}$ ), in upstream reaches (mean water depth lower than $0.2 \mathrm{~m}$ ) with low mineralization level. Northern river basins represented $44 \%$ of fishless sites (Minho, Lima, Cávado and Douro river basins).

Hierarchical Cluster Analysis performed on fish species composition allowed identifying 10 fish-groups (Figure 3), further characterized concerning fish metrics and guilds (Table II).

Group 1 included streams from the Littoral, both in the Centre and North regions with a clear dominance of Achondrostoma oligolepis. The most representative guilds were omnivorous, limnophilic and phytophilic individuals. Nevertheless, salmonids also presented some expression, accounted for the significant presence of Salmo trutta, comparatively to other groups, making this group a mixed cyprinid-salmonid one. This group presented high fish density (mean $=37.7$ ind. $/ 100 \mathrm{~m}^{2}, \mathrm{SD}=43.5$ ), species richness (mean $\mathrm{S}=5.2 ; \mathrm{SD}=2.3$ ) and diversity (mean $\mathrm{H}=1.1$; $\mathrm{SD}=0.5$ ) per site. 


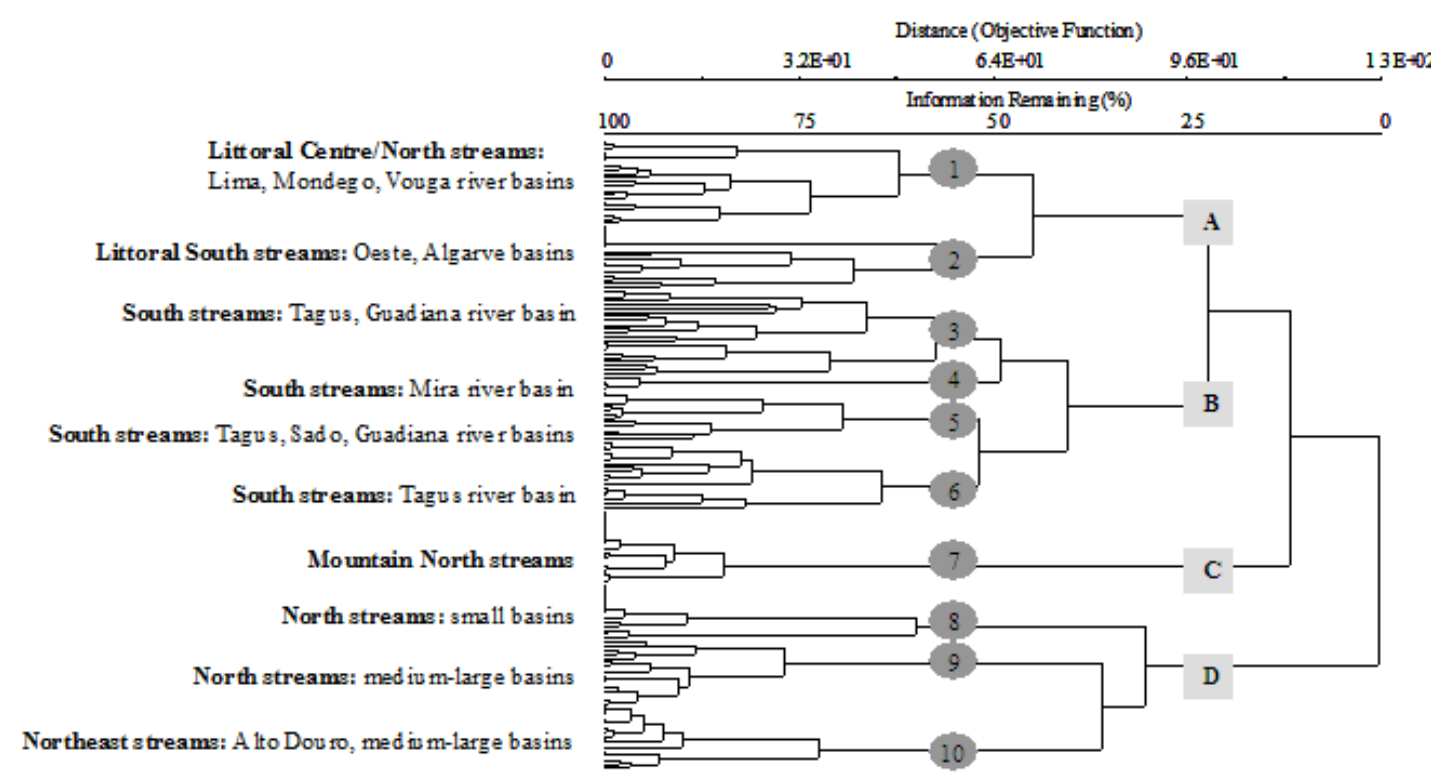

\section{Figure 3}

Cluster of the sampled sites based on fish species densities identifying 10 fish-groups and 4 fish-regions.

Groups 2, 3, 4, 5 and 6 belonged to the South region of Portugal. Group 2 included the southern Littoral river basins from Algarve region. The dominant species were Squalius aradensis and Anguilla anguilla. Group 3 was mostly represented by streams from Guadiana river basin. The dominant species were Squalius alburnoides and the endemic barbels from Guadiana basin, especially Barbus microcephalus. Group 4 was represented by streams from Mira river basin. Fish assemblages were dominated by Squalius torgalensis, endemic from this basin. Group 5 was represented by fish assemblages common to Guadiana, Sado and Tagus river basins. Squalius alburnoides was the most representative and abundant species, followed by Squalius pyrenaicus. Group 6 was mostly represented by streams from Tagus river basin, therefore located in a transitional region between the North and the South of Portugal. Fish assemblages were dominated by Barbus bocagei, Pseudochondrostoma polylepis and Squalius pyrenaicus.

Overall, compared to the other fish-groups, southern ones showed high abundance of Squalius spp, followed by barbel species. Fish assemblages were dominated for eurytopic, water column, lithophilic and insectivorous individuals. Most of these groups showed high fish density, including the group with the highest values of total density (mean $=73.7$ ind. $/ 100 \mathrm{~m}^{2}$; $\mathrm{SD}=97.2)$ and total captured species $(N=18)$. Nevertheless, mean species richness and mean diversity were high only in groups 3,5 and 6 .

It was possible to identify two main functional units in the southern fish-groups: groups 2, 4 and 5 were clearly dominated by eurytopic and water column insectivorous cyprinids, while in groups 3 and 6 this pattern was less obvious, because they also showed high percentages of omnivorous individuals, due to the marked presence of barbel and nase species. Moreover, these last two groups presented higher percentages of rheophilic individuals than the other southern fish-groups and the highest values of species richness and diversity within the South.

Group 7 included small mountain streams from the North and was mostly represented by Salmo trutta. Therefore, was highly discriminated by salmonid, rheophilic and insectivorous guilds. Fish assemblages presented low density (mean $=5.84$ ind. $/ 100 \mathrm{~m}^{2}$; $\mathrm{SD}=6.6$ ), diversity (mean $\mathrm{H}=0.5 ; \mathrm{SD}=0.5$ ) and species richness (mean $\mathrm{S}=2.1 ; \mathrm{SD}=1.2$ ). 


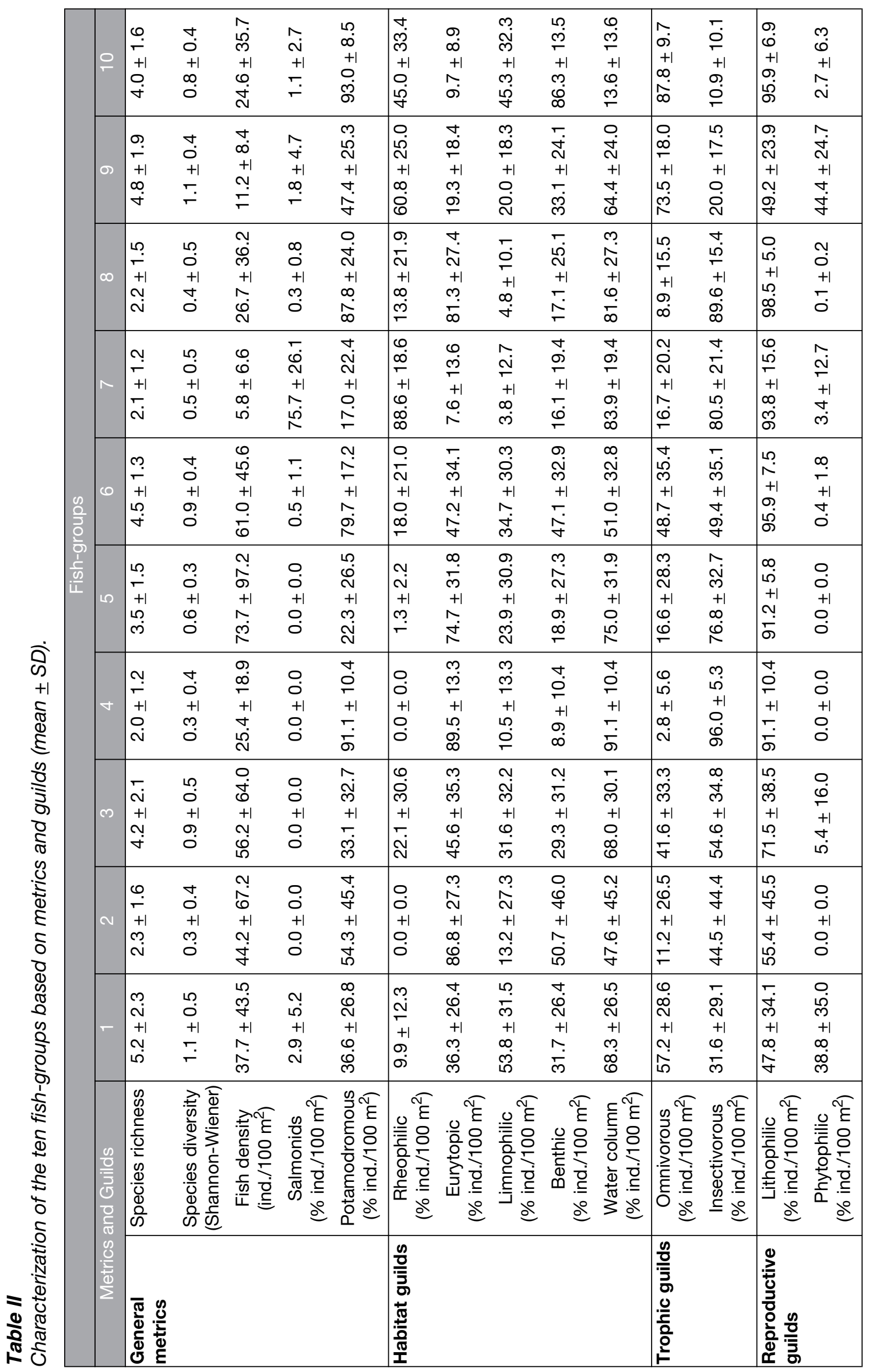


ANOSLM based on fish composition

\begin{tabular}{|c|c|c|c|c|c|c|c|c|c|c|}
\hline & 1 & 2 & 3 & 4 & 5 & 6 & 7 & 8 & 9 & 10 \\
\hline 1 & & 0.67 & 0.6 & 0.94 & 0.79 & 0.73 & 0.83 & 0.62 & 0.66 & 0.73 \\
$* * *$ & $* * *$ & $* * *$ & $* * *$ & $* * *$ & $* * *$ & $* * *$ & $* * *$ & $* * *$ \\
\hline
\end{tabular}

\section{Figure 4}

Results from Similarity Analysis (ANOSIM) between fish-groups, based on fish composition and on fish metrics and guilds. Significance levels for $P<0.001\left(^{(* *}\right), P<0.01\left(^{* *}\right), P<0.05\left(^{*}\right)$ and $P>0.05$ (ns).

Group 8 included small permanent streams from the North. The most abundant species was Squalius carolitertii and fish assemblages were mainly composed by water column, insectivorous, eurytopic, and lythophilic species. Relatively low values of total density ( mean $=26.7$ ind.$/ 100 \mathrm{~m}^{2} ; \mathrm{SD}=36.2$ ), species richness (mean $\mathrm{S}=2.2 ; \mathrm{SD}=1.5$ ) and diversity (mean $\mathrm{H}=0.4$; $\mathrm{SD}=0.5$ ) were also observed per site.

Group 9 was represented by North streams with medium and large drainage area. The most abundant species was Achondrostoma arcasii, but Squalius carolitertii and Barbus bocagei were represented as well. Fish assemblages were dominated by omnivorous, phytophilic, water column and rheophilic individuals. Although mean total density was low (mean = 11.2 ind. $/ 100 \mathrm{~m}^{2} ; \mathrm{SD}=8.4$ ), species richness (mean $\mathrm{S}=4.8 ; \mathrm{SD}=1.9$ ) and diversity (mean $\mathrm{H}=$ $1.1 ; \mathrm{SD}=0.4$ ) showed high values per site.

Group 10 represented a particular area of Douro river basin named Alto Douro in the Northeast of Portugal. Though Squalius carolitertii occured with relatively high density, fish assemblages were dominated by Barbus bocagei and Pseudochondrostoma duriense. Therefore, high values of potamodromous, omnivorous and rheophilic individuals were registered. Density per site was relatively low (mean $=24.6$ ind.$/ 100 \mathrm{~m}^{2} ; \mathrm{SD}=35.7$ ), but number of species (mean $\mathrm{S}=4 ; \mathrm{SD}=1.6$ ) and diversity (mean $\mathrm{H}=0.8 ; \mathrm{SD}=0.4$ ) were high.

ANOSIM results considering fish composition showed significant differences $(P<0.05)$ and a good separation ( $R>0.75$ or near) between most of the groups, particularly for groups 4 and 7 (Figure 4). Significant, though lower $R$ values ( $<0.5$ or near) were obtained among southern fish-groups (2, 3, 4, 5 and 6) and also between northern groups 8, 9 and 10, reflecting an overlapping or even a close taxonomic similarity between some of these groups. 
Concerning metrics and guilds, in general, ANOSIM results revealed lower $R$ values than for fish composition (Figure 4). Significant similarities $(R<0.5$ and $P<0.05$ or $P>0.05-$ n.s.) were verified between several groups, especially among the southern ones (2, 3, 4, 5 and 6), emphasizing taxonomic results. North groups 8, 9 and 10 showed less functional similarities among them than it has been observed for fish composition. These three fish-groups also presented functional similarities with some South and Littoral groups, particularly fishgroup 8. In fact, this group was dominated by Squalius carolitertii, thereby presenting high proportions of insectivorous, eurytopic, water column and lithophilic individuals, which also characterized South fish-groups. Group 7 was the most functionally distinct.

There was a clear correspondence of the 10 fish-groups to the river basin level, due to the restrict basin distribution of many species, and a trend division between North and South. Fish-groups showed a wider aggregation in 4 regions (Figures 3 and 6): (i) Region A including sites nearby Littoral areas; (ii) Region B including sites from the South region, namely Tagus, Sado, Mira and Guadiana river basins; (iii) Region C including sites from the Mountain North region; and (iv) group $D$ including sites from the North region. These regions showed a broader geographical correspondence than fish-groups, though region A seemed rather fragmented. ANOSIM results supported this major division but suggested more taxonomic and functional similarities between group 2 and the South fish-groups $(3,4,5$ and 6$)$ than with group 1 from the same Littoral region.

\section{> ENVIRONMENTAL DRIVERS}

Principal Components Analysis (PCA) revealed a good segregation of sites along the first two ordination axes, which together accounted for $70 \%$ of total variation (Figure 5).

Overall, large-scale and regional variables assumed more relevance discriminating species and sites than the local ones. According to the correlations between environmental variables and PCA axes, drainage area $(r=0.83)$, conductivity $(r=0.69)$, precipitation $(r=-0.65)$, annual discharge $(r=-0.58)$, altitude $(r=-0.58)$ and mean annual temperature $(r=0.52)$ were the most important variables for the first axis, whereas mean stream width $(r=-0.81)$, latitude $(r=$ -0.66), conductivity $(r=0.65)$, mineralization $(r=0.59)$, mean water deph $(r=-0.58)$, drainage area $(r=-0.54)$ and mean annual temperature $(r=0.52)$ were the variables with the highest contributions to the second axis (Table III).

PCA biplot considering fish-groups showed a discrimination along a North-South gradient, mostly defined by the second axis (Figure 5). North fish-groups were associated with low annual temperature, mineralization and conductivity, high altitude, annual discharge and local variables reflecting high flow conditions and permanent flow regime: high current velocity, coarser dominant substrate and high percentage of turbulent habitats. South fish-groups exhibited less diverse environmental features and were mainly associated with high temperature, mineralization and conductivity, low alitude, annual discharge and high percentage of slow current habitats. The first axis mainly discriminated the North fish-groups (Figure 5). Groups 7 and 8 were associated with higher altitude and annual discharge and small drainage area, compared to fish-groups 9 and 10. South groups were quite dispersed along this axis, particularly group 6 . This group represented the majority of Tagus river basin, located in the transition area between the North and the South regions, thus sharing environmental influences with both. Littoral fish-groups showed a scattered distribution along both axes, though group 1 seemed closer to North groups and group 2 to the South ones.

Together with ANOSIM, PCA results supported the existence of 4 fish-based major regions in continental Portugal with a meaningful biological and environmental correspondence (Figure 6). Results further suggest including group 2 in the fish-region B, unifying the geographical area of the South (Figure 6). General characterization of the 4 fish-regions is given bellow:

Mountain fish-region (fish-group 7) corresponded to small headwater streams of northern mountain basins. These sites presented low mineralization, conductivity and annual temperature and were located in the highest altitude areas, with high slope, permanent flow and cold water. Salmo trutta was the most abundant and indicator species. 


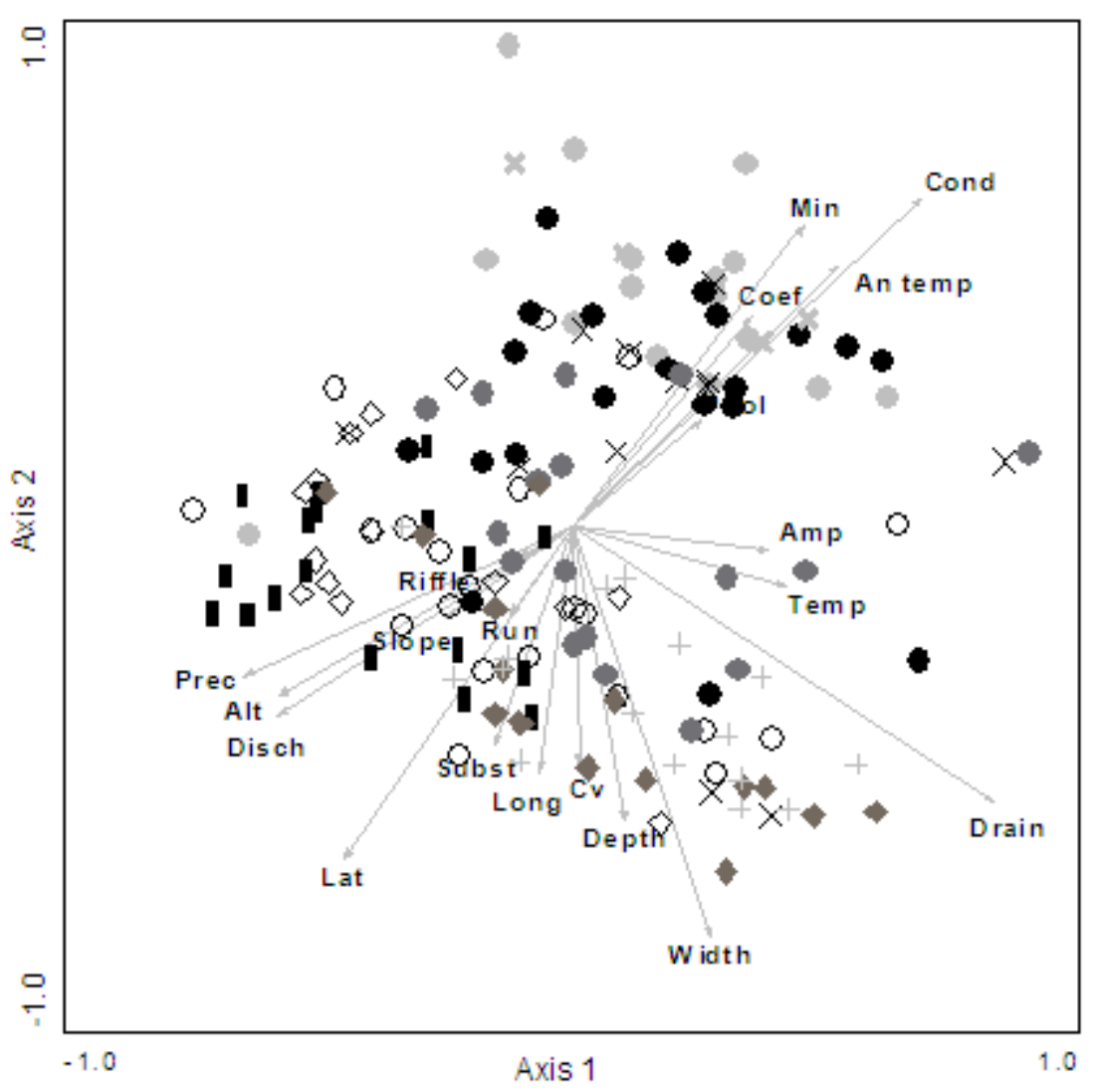

Fish-Groups

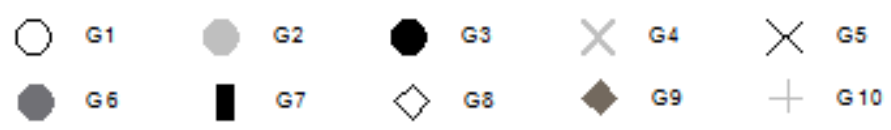

\section{Figure 5}

Ordination diagram (biplot) of Principal Components Analysis (PCA) based on the environmental variables of sampled sites. Sites are coded according to fish-groups. Variables abbreviations: latitude (Lat), longitude (Long), altitude (Alt), mineralization (Min), conductivity (Cond), mean annual air temperature (An temp), thermal amplitude (Amp), water temperature (Temp), precipitation (Prec), coefficient of variation of precipitation (Coef), drainage area (Drain), mean annual discharge (Disch), mean stream width (width), mean water depth (Depth), current velocity (Cv), dominant substrate class (Subst).

North fish-region (fish-groups 8, 9 and 10) included most of the North river basins and presented rather similar characteristics, though less marked, to the Mountain fish-region. As such, sites generally showed low mineralization, conductivity and annual temperature, but variable altitude, flow and drainage area. Squalius carolitertii and Pseudochondrostoma duriense were the indicator species.

Littoral/Centre fish-region (fish-group 1) included streams from the Littoral area, both in the Centre and North, therefore tend to have environmental characteristics closer to the North fish-region. Achondrostoma oligolepis was the most abundant and indicator species.

South fish-region (fish-groups 2, 3, 4, 5 and 6) corresponded to lowland streams and included the South river basins. These streams were mainly discriminated by high annual temperature, mineralization and conductivity and low annual flow. Squalius alburnoides and Squalius pyrenaicus were the indicator species. 
Table III

Largest absolute correlations between each environmental variable and the first two ordination axes of Principal Components Analysis.

\begin{tabular}{|l|c|c|}
\hline \multirow{2}{*}{} & \multicolumn{2}{|c|}{ Correlation coefficients } \\
\cline { 2 - 3 } & Axis 1 & Axis 2 \\
\hline Drainage area $\left(\mathbf{k m}^{\mathbf{2}}\right)$ & $\mathbf{0 . 8 3}$ & $-\mathbf{0 . 5 4}$ \\
\hline Conductivity $\left(\mu \mathbf{s} \cdot \mathbf{c m}^{-\mathbf{1}}\right)$ & $\mathbf{0 . 6 9}$ & $\mathbf{0 . 6 5}$ \\
\hline Mean annual precipitation $(\mathbf{m m})$ & $-\mathbf{0 . 6 5}$ & -0.29 \\
\hline Mean annual discharge $(\mathbf{m m})$ & $-\mathbf{0 . 5 8}$ & -0.37 \\
\hline Altitude & $-\mathbf{0 . 5 8}$ & -0.33 \\
\hline Mean annual temperature $\left({ }^{\circ} \mathbf{C}\right)$ & $\mathbf{0 . 5 2}$ & $\mathbf{0 . 5 2}$ \\
\hline Mean stream width $(\mathbf{m})$ & 0.27 & $-\mathbf{0 . 8 1}$ \\
\hline Mean water depth $(\mathbf{m})$ & 0.10 & $-\mathbf{0 . 5 8}$ \\
\hline Latitude & -0.45 & $-\mathbf{0 . 6 6}$ \\
\hline Mineralization & 0.45 & $\mathbf{0 . 5 9}$ \\
\hline
\end{tabular}

\section{DISCUSSION}

The Iberian Peninsula was considered by Illies (1978) as an ecoregion. However, the Portuguese continental territory includes a diverse array of lotic ecosystems (permanent, intermittent and ephemeral). A large environmental gradient from North to South exists with a high spatial complexity from climatic, geomorphological and hydrological points of view. This heterogeneity causes considerable difficulties in the development of a river typology, either biotic or abiotic, and is further amplified by a long history of human-induced pressures. Indeed, Mediterranean rivers are especially susceptible to degradation due to high human settlement and progressively more intensive agricultural production. In some regions the variety and ubiquity of human pressures hampers to attain a set of reference sites completely absent from anthropogenic stress, and consequently researchers settle for 'least disturbed' or 'best available' sites. This can make reference condition less consistent, which may not correctly represent biological potential in the absence of anthropogenic disturbance (Chessman, 2001). This issue is of major importance when evaluating ecological quality through the deviation from reference condition (Hawkins et al., 2010), being fundamental to consider changes that these modifications entail and evaluate their ecological influence (Monaghan et al., 2008). In this study, reference sites were selected in compliance with the WFD normative and objectives. Even when least disturbed sites were considered, this didn't compromise the set of a reference condition, as no significant differences were detect between undisturbed and least disturbed sites $(R<0.5$ and $P>0.05)$.

Introduction of new species and other human interventions can influence assemblage composition in streams (Vila-Gispert et al., 2002). Homogenization of regional fish faunas by widespread species introductions or extinction of endemic species may blur the roles played by historical factors such as colonization and speciation in shaping local assemblages (Rahel, 2000; Olden and Poff, 2003; Clavero and Garcia-Berthou, 2006; Leprieur et al., 2008;). In the present study, the definition of fish-groups/regions were not influenced by this effect, as collected data showed low occurrence and abundance of non-native species (about $2 \%$ of fish density in all captures).

Due to long-lasting isolation periods punctuated by southward European and northward African movements, lberian rivers generally present low species richness per site and a high 


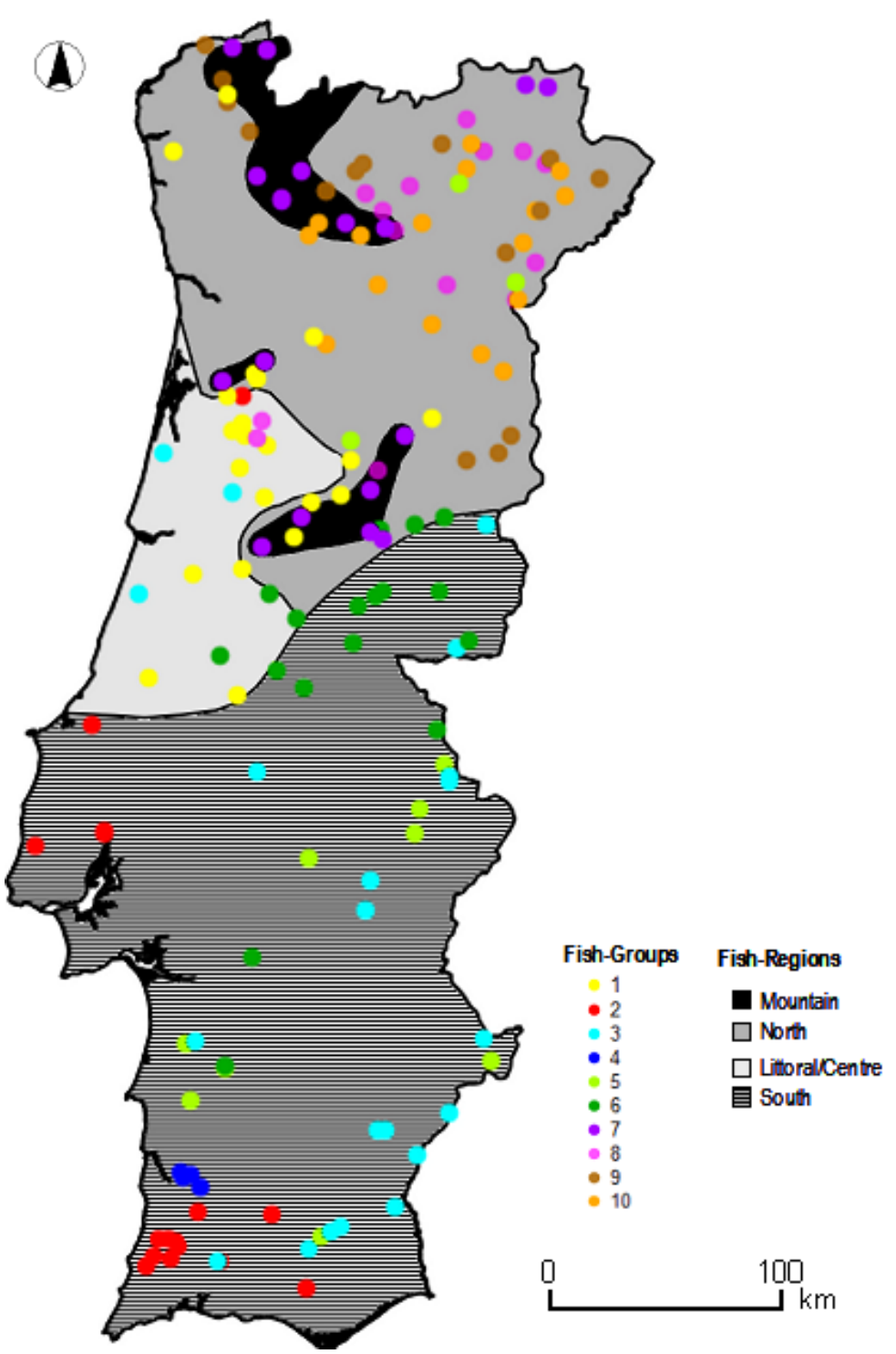

\section{Figure 6}

Map with de geographical location of the 4 Portuguese fish-regions and the projection of sampled sites according to the 10 fish-groups.

degree of endemicity (dominated by cyprinids), as many species are exclusive from a particular river basin (Ferreira and Oliveira, 2004). The isolation of the small South basins enabled the speciation of several different species, as is the case of the Squalius genus. In the northern part of the territory only one endemism exists - Pseudochondrostoma duriense.

To freshwater fish, barriers to dispersal are a major constraint to primary species distribution and strongly influence spatial patterns of assemblage composition. Barriers such as basin boundaries are frequently considered as relevant determinants of the geographical patterns of freshwater fishes and not the current environmental conditions (e.g. Williams et al., 2003; Smith and Bermingham, 2005; Filipe et al., 2009). Results revealed that the first level of fishgroups differentiation was due to fish composition, particularly related to occurrence of endemic species in small basins. It is the case of groups 2 and 4, in the South of Portugal, 
which were formed owing to the occurrence of the endemic Squalius aradensis in Algarve streams and Squalius torgalensis in the small basin of Mira river.

Ecologists increasingly recognize that local communities (i.e. communities sampled at a small spatial extent) are structured by a combination of historic, regional, and local factors operating at different spatial and temporal scales (Poff, 1997; Whittaker et al., 2001; Hoeinghaus et al. 2007). Whether are large-scale (Schlosser, 1991; Marsh-Matthews and Matthews, 2000; Magalhães et al., 2002a; Hoeinghaus et al., 2007) or local environmental factors (Ricklefs and Schluter, 1993; Ricklefs, 2006), the principal determinants of community structure continuous to be a widely debated issue. At larger spatial scales, historic (e.g. speciation and dispersal) and regional (e.g. geology and climate) factors determine the composition of available species from which local communities are assembled. Local factors, both biotic interactions and abiotic constraints, often dictate which of the species from the regional pool will occupy a particular community and in what abundance. Moreover regional factors can interact with local factors altering the degree to which biotic or abiotic determinants influence local community structure.

Fish assemblages patterns exhibited a strong association with large-scale spatial patterns. Fish-groups were hierarchically grouped over major and local regions, expressing a largescale response to the North-South environmental gradient defined by temperature, precipitation, mineralization and altitude, and a regional-scale response mainly to drainage area and flow discharge. In streams with strong seasonal and annual environmental variation, fish abundance and distribution probably bear little relationship to local habitat features (Angermeier and Schlosser, 1989). This may be the case in Mediterranean streams, where the prevailing patterns of surface water distribution across stream networks result to a large extent from processes operating over large spatial scales, such as the regional climate patterns, groundwater seepage, geomorphology and catchment geometry (Sabater et al., 1995).

The environmental North-South gradient is followed by a considerable shift in the composition and structure of fish communities. There was an increase in species number towards South, particularly endemic cyprinids, reaching the maximum value in Guadiana river basin (Almaça, 1978). Furthermore, the North fish-groups, particularly the Mountain one, presented the lowest fish density (Shannon-Wiener Index) and diversity, while the South and the Littoral/Centre fish-groups showed the highest fish abundances.

Drainage area and flow discharge were also determinant factors in distinguishing fish-based geographical groups. With the increase in river size, fish assemblages shifted both taxonomically and functionally (Vannote et al., 1980). Small streams are highly variable according to climate, morphology and flow discharge. As a result, these streams are typically inhabited by low numbers of species, which is in accordance with ecological theory of species-area relationships (e.g. MacArthur and Wilson, 1967; Borda de Água et al., 2002; Ricotta et al., 2002). In this study, 3-5 species were recorded in the small upland streams (within Mountain, North, and South regions), a number which can increased up to 10 species in river sites with medium to large drainage area (particularly in the lowland groups). Accordingly, similar pattern in species diversity was observed. These results are in accordance with numerous previous studies (Godinho et al., 1997, 2000; Carmona et al., 1999; Pires et al., 1999, 2004; Mesquita and Coelho, 2002; Magalhães et al., 2002a, 2002b, 2007; Clavero et al., 2004; Ferreira and Oliveira, 2004; Clavero and Garcia-Berthou, 2006; Mesquita et al., 2006; Ferreira et al., 2007a, 2007b). In fact, increasing local species richness along the longitudinal stream gradient is a very well known pattern (e.g. Oberdorff et al., 1995; Pont et al., 1995; Grenouillet et al., 2004) that has been observed on almost all continents (Ibañez et al., 2009).

As expected, the well oxygenated, summer-cold rhithral and small permanent upland basins (e.g. Mountain fish-region) were inhabited by cold adapted, rheophilic and rheopar species, whereas the lowland rivers, particularly in downstream sectors, were occupied by eurytopic, and rheo-tolerant species (e.g. Huet, 1949; Fieseler and Wolter, 2006), clearly dominated by cyprinids. The sampled rhithral streams were generally occupied by insectivorous and 
sand-or gravel-spawning species, which in the case of the Mountain fish-region (fish-group 7) were mainly represented by trout, Salmo trutta, while in the fish-group 8 cyprinid species were dominant, particularly Squalius carolitertii. Within the same latitudes (i.e. in the northern basins), larger rivers with high flow discharge presented higher number of fish species and fish diversity. In the case of fish-group 9 fish assemblages were represented by reophilic species, both cyprinid and salmonids, with Achondrostoma arcasii as the dominant species, while fishgroup 10 (mainly Alto-Douro) was mostly represented by potamodromous, limnophilic and omnivorous species, with fish assemblages dominated by Barbus bocagei and Pseudochondrostoma duriense.

All the southern streams and rivers showed a dominance of eurytopic, lithophilic and insectivorous cyprinids, mainly represented by roach species, Squalius spp. The association of these species to lowland, summer-warm, potamal streams have been reported also in other studies (e.g. Ferreira and Oliveira, 2004; Fieseler and Wolter, 2006).

The aggregation of fish-groups into 4 fish-based regions of continental Portugal presented a strong biological and environmental correspondence. Results further suggested including fish-group 2 in the fish-region B, unifying the geographical area of the South. The complementary use of both taxonomic and functional traits of fish assemblages was fundamental to interpret these results. The composition of traits in lotic fish communities appears to be structured along an environmental gradient (Pont et al., 2006, 2007; Hoeinghaus et al., 2007; Ibañez et al., 2007, 2009; Logez et al., 2010), whereas patterns derived from taxonomic composition reflect the role played by geographical and historical factors in species distribution (Hoeinghaus et al., 2007).

From North to South, and expressing an altitude and climate gradient, fish-regions related to the morphoclimatic regions (the base of abiotic typology) (Figures 1 and 6). The Mountain fishregion overlaps with the morphoclimatic region 6 of the abiotic typology. In general, this high slope mountain region showed high precipitation and low mineralization, representing the typical small trout streams. The North fish-region included rather different rivers, both lowland and altitude ones, with variable flow and drainage area, and low mineralization. This fishregion corresponds to morphoclimatic regions 3, 4 and 5 . Littoral/Centre fish-region was also quite heterogeneous and includes areas both from morphoclimatic region 2 and 3 . The South fish-region (merging fish-groups 2, 3, 4, 5 and 6) included intermittent lowland rivers, located in low altitude, with relatively low flow discharge and high conductivity. It corresponds to morphoclimatic regions 1 and 2 .

Though no perfect overlap between fish-regions and the morphoclimatic regions exists, a certain agreement is observed mainly in the extremes of the environmental gradient. The validation of the abiotic typology by significantly independent fish groups/regions is important to ensure the reliability of fish assemblages in a certain river-type, and therefore the accuracy of the ecological assessment (as already discussed above).

The fish grouping obtained in this study was in general consistent with previous patterns observed for the Iberian Peninsula (e.g. Ferreira and Oliveira, 2004; Ferreira et al., 2007a). These results, along with those obtained from the other biological elements considered in the WFD, were used to set the final typology for Portuguese rivers (INAG, 2008a) and constitutes a fundamental tool in planning and managing of water resources. It allows to evaluate the changes undergone by the river ecosystem and therefore the effectiveness of mitigation and recovery measures considered necessary to accomplish the WFD objectives.

\section{ACKNOWLEDGEMENTS}

This study was part of a larger program on the implementation of the Water Framework Directive, partially funded by the Portuguese Water Agency (INAG). P. Matono was supported by a Ph.D. grant from FCT (Fundação para a Ciência e Tecnologia). The authors wish to thank all the fieldwork teams involved in the program and Rute Caraça for GIS support. The National Forest Authority provided the necessary fishing permits. 


\section{REFERENCES}

Almaça C., 1978. Répartition géographique des Cyprinidae ibérique et secteurs ichtyogéographiques de la Péninsule Ibérique. Vestník Ceskoslovenské Spolecnosti Zoologické, XLII, 241-248.

Alves M.H., Bernardo J.M., Figueiredo H., Pádua J., Pinto P. and Rafael T., 2004. Aplicação do Sistema B da Directiva-Quadro da Água na identificação de tipos de rios em Portugal Continental, Actas do $7^{\circ}$ Congresso da Água, Associação Portuguesa dos Recursos Hídricos, Lisboa, 1-14.

Angermeier P.L. and Schlosser I.J., 1989. Species-area relationships for stream fishes. Ecology, 70, 1450-1462.

Barbour M.T., Gerritsen J., Snyder B.D. and Stribling J.B., 1999. Rapid Bioassessment Protocols for Use in Streams and Wadeable Rivers: Periphyton, Benthic Macroinvertebrates and Fish, 2nd edition, EPA 841-B-99-002, U.S. Environmental Protection Agency, Office of Water, Washington, DC.

Bernardo J.M. and Alves M.H., 1999. New perspectives for ecological flow determination in semi-arid regions: a preliminary approach. Regul. River, 15, 221-229.

Bernardo J.M., Ilhéu M., Matono P. and Costa A.M., 2003. Interannual variation of fish assemblage structure in a Mediterranean river: implications of streamflow on the dominance of native or exotic species. River Res. Appl., 19, 521-532.

Borda-de-Água L., Hubbell S.P. and McAllister M., 2002. Species-area curves, diversity indices, and species abundance distributions: a multifractal analysis. Am. Nat., 159, 138-155.

Cabral M.J., Almeida J., Raposo de Almeida P., Dellinger T.R., Ferrand de Almeida N., Oliveira M., Palmeirim J.M., Queiroz A.I., Rogado L. and Santos-Reis M., 2005. Livro Vermelho dos Vertebrados de Portugal, Instituto da Conservação da Natureza, Lisboa.

Caetano M., Nunes V. and Nunes A., 2009. CORINE Land Cover 2006 for Continental Portugal, Instituto Geográfico Português.

Carmona J.A., Doadrio I., Marquez A.L., Real R., Hugueny B. and Vargas J.M., 1999. Distribution patterns of indigenous freshwater fishes in the Tagus River basin, Spain. Environ. Biol. Fish., 54, 371-387.

CEN, 2003. Water Quality-Sampling of Fish with Electricity, European standard-EN 14011:2003, European Committee for Standardization, Brussels.

Chaves M.L., Costa J.L., Chainho P., Costa M.J. and Prat N., 2006. Selection and validation of reference sites in small river basins. Hydrobiologia, 573, 133-154.

Chessman B.C., 2001. Prediction of riverine fish assemblages through the concept of environmental filters. Mar. Freshw. Res., 57, 601-609.

CIS-WFD, 2003. Guidance on Establishing Reference Conditions and Ecological Status Class Boundaries for Inland Surface Waters, Final Version, EU Common Implementation Strategy for the Water Framework Directive. Available at http://ec.europa.eu/environment/water/waterframework/index_en.html.

Clarke K.R. and Gorley R.N., 2001. PRIMERv5: User Manual/Tutorial, PRIMER-E, Plymouth, UK.

Clarke K.R. and Warwick R.M., 1994. Change in Marine Communities: an Approach to Statistical Analysis and Interpretation, Plymouth Marine Laboratory, Plymouth, UK.

Clavero M. and Garcia-Berthou E., 2006. Homogenization dynamics and introduction routes of invasive freshwater fish in the Iberian Peninsula. Ecol. Appl., 16, 2313-2324.

Clavero M., Blanco-Garrido F. and Prenda J., 2004. Fish fauna in Iberian Mediterranean river basin: biodiversity, introduced species and damming impacts. Aquat. Conserv., 14, 575-585.

Clesceri, L.S., Greenberg A.E. and Eaton A.D. (eds.), 1998. Standard methods for the examination of water and wastewater, 20th edition, American Public Health Association, American Water Works Association, Water Environmental Federation, Washington, DC.

Doadrio I., 2002. Atlas y Libro Rojo de los Peces Continentales de España, Ministerio de Medio Ambiente, Madrid.

Dodkins I., Rippey B., Harrington T.J., Bradley C., Chathain B.N., Kelly-Quinn M., McGarrigle M., Hodge S. and Trigg D., 2005. Developing an optimal river typology for biological elements within the Water Framework Directive. Water Res., 39, 3479-3486.

Dufréne M. and Legendre P., 1997. Species assemblages and indicator species: the need for a flexible asymmetrical approach. Ecol. Monogr., 67, 345-366.

European Commission, 2000. Directive 2000/60/EC. Establishing a framework for community action in the field of water policy, European Commission PE-CONS 3639/1/100, Luxembourg. Available at http://ec.europa.eu/environment/water/water-framework/index_en.html. 
FAME, 2004. Development, Evaluation and Implementation of a Standardised Fish-based Assessment Method for the Ecological Status of European Rivers - A Contribution to the Water Framework Directive, Final Report, scientific achievements (Sections 5 and 6) (Co-ordinator: Stefan Schmutz), Institute for Hydrobiology and Aquatic Ecosystem Management, University of Natural Resources and Applied Life Sciences, Vienna. Available at http://fame.boku.ac.at.

Ferreira M.T. and Oliveira J., 2004. Fish-based quality assessment of Iberian rivers using a spatial approach, Proceedings of the 5th International Symposium on Ecohydraulics, Madrid, Vol. 1, 198-204.

Ferreira M.T., Oliveira J., Caiola N., de Sostoa A., Casals F., Cortes R., Economu A., Zogaris S., GarciaJalon D., Ilhéu M., Martinez-Capel F., Pont D., Rogers C. and Prenda J., 2007a. Ecological traits of fish assemblages from Mediterranean Europe and their responses to human disturbance. Fish. Manag. Ecol., 14, 473-481.

Ferreira M.T., Sousa L., Santos J.M., Reino L., Oliveira J., Raposo de Almeida P. and Cortes R., $2007 \mathrm{~b}$. Regional and local environmental correlates of native Iberian fish fauna. Ecol. Freshwater Fish, 16, 504-514.

Fieseler C. and Wolter C., 2006. A fish-based typology of small temperate rivers in the northeastern lowlands of Germany. Limnologica, 36, 2-16.

Filipe A.F., Araújo M.B., Doadrio I., Angermeier P.L. and Collares-Pereira M.J., 2009. Biogeography of the Iberian Freshwater Fishes revisited: the role of contemporary versus historical constraints. $J$. Biogeogr., doi:10.1111/j.1365-2699.2009.02154.x.

Gasith A. and Resh V.H., 1999. Streams in Mediterranean climate regions: abiotic influence and biotic responses to predictable seasonal events. Annu. Rev. Ecol. Syst., 30, 51-81.

Giller P.S. and Malmqvist B., 1998. The biology of streams and rivers, Oxford University Press, New York.

Godinho F.N., Ferreira M.T. and Cortes R., 1997. Composition and spatial organization of fish assemblages in the lower Guadiana basin, southern Iberia. Ecol. Freshwater Fish, 6, 134-143.

Godinho F.N., Ferreira M.T. and Santos J.M., 2000. Variation in fish community composition along an Iberian river basin from low to high discharge: relative contributions of environmental and temporal variables. Ecol. Freshwater Fish, 9, 22-29.

Grenouillet G., Pont D. and Chérisse C., 2004. Within-basin fish assemblage structure: the relative influence of habitat versus stream spatial position on local species richness. Can. J. Fish. Aquat. Sci., 61, 93-102.

Griffiths D., 2006. Pattern and process in the ecological biogeography of European freshwater fish. J. Anim. Ecol., 75, 734-751.

Hawkins C.P., Cao Y. and Roper B., 2010. Method of predicting reference condition biota affects the performance and interpretation of ecological indices. Freshw. Biol., 55, 1066-1085.

Higgins C.L. and Strauss R.E., 2008. Modeling stream-fish assemblages with niche apportionment models: patterns, processes, and scale dependence. Trans. Am. Fish. Soc., 137, 696-706.

Hoienghaus D.J., Winemiller K.O. and Birnbaum J.S., 2007. Local and regional determinants of stream fish assemblage structure: inferences based on taxonomic vs. functional groups. J. Biogeogr., 34, 324-338.

Holzer S., 2008. European fish species: taxa and guilds classification regarding fish-based assessment methods, Ph.D. thesis, Universitat fur Bodenkultur.

http://geo.snirh.pt/AtlasAgua (accessed 3 November 2011).

http://www.igeo.pt/atlas/ (accessed 3 November 2011).

Huet M., 1949. Aperçu des relations entre la pente et les populations piscicoles des eaux courantes. Scheiw. Z. Hydrol., 11, 332-335.

Ibañez C., Oberdorff T., Teugels G., Mamononekene V., Lavoue S., Fermon Y., Paugy D. and Toham A.K., 2007. Fish assemblages structure and function along environmental gradients in rivers of Gabon (Africa). Ecol. Freshwater Fish, 16, 315-334.

Ibañez C., Belliard J., Hughes R.M., Irz P., Kamdemtoham A., Lamouroux N., Tedesco P.A. and Oberdorff T., 2009. Convergence of temperate and tropical stream fish assemblages. Ecography, 32, 658-670.

Ilhéu M., 2004. Padrões de uso de habitat da ictiofauna em rios de tipo mediterrânico, Tese de Doutoramento, Universidade de Évora.

Illies J., 1978. Limnofauna Europaea, Gustav Fischer Verlag, Stuttgart.

INAG I.P., 2008a. Tipologia de Rios em Portugal Continental no âmbito da implementação da Directiva Quadro da Água. I - Caracterização abiótica, Ministério do Ambiente, do Ordenamento do Território e do Desenvolvimento Regional, Instituto da Água, IP. Available at http://dqa.inag.pt. 
INAG I.P., 2008b. Manual para a avaliação biológica da qualidade da água em sistemas fluviais segundo a Directiva Quadro da Água Protocolo de amostragem e análise para a fauna piscícola, Ministério do Ambiente, do Ordenamento do Território e do Desenvolvimento Regional, Instituto da Água, IP. Available at http://dqa.inag.pt.

Karr J.R. and Chu E.W., 1999. Restoring Life in Running Waters: Better Biological Monitoring, Island Press, Washington.

Legendre P. and Legendre L., 1998. Numerical ecology, 2nd edition, Elsevier, Amsterdam.

Leprieur F., Beauchard O., Blanchet S., Oberdorff T. and Brosse S., 2008. Fish invasions in the world's river systems: when natural processes are blurred by human activities. PloS Biol., 6, 404-410.

Levin N., Elron E. and Gasith A., 2009. Decline of wetland ecosystems in the coastal plain of Israel during the 20th century: implications for wetland conservation and management. Landsc. Urban Plan., 92, 220-232.

Logan P. and Furse M., 2002. Preparing for the European Water Framework Directive - making the links between habitat and aquatic biota. Aquat. Conserv., 12, 425-437.

Logez M., Pont D. and Ferreira M.T., 2010. Do Iberian and European fish faunas exhibit convergent functional structure along environmental gradients? J. North Am. Benthol. Soc., 29, 1310-1323.

MacArthur R.H. and Wilson E.O., 1967 The Theory of Island Biogeography, Princeton University Press, Princeton, NJ.

Magalhães M.F., Batalha D.C. and Collares-Pereira M.J., 2002a. Gradients in stream fish assemblages across a Mediterranean landscape: contributions of environmental factors and spatial structure. Freshw. Biol., 47, 1015-1031.

Magalhães M.F., Beja P., Canas C. and Collares-Pereira M.J., 2002b. Functional heterogeneity of dryseason fish refugia across a Mediterranean catchment: the role of habitat and predation. Freshw. Biol., 47, 1919-1934.

Magalhães M.F., Beja P., Schlosser I.J. and Collares-Pereira M.J., 2007. Effects of multi-year droughts on fish assemblages of seasonally drying Mediterranean streams. Freshw. Biol., 52, 1494-1510.

Magalhães M.F., Ramalho C.E. and Collares-Pereira M.J., 2008. Assessing biotic integrity in a Mediterranean watershed: development and evaluation of a fish-based index. Fish. Manag. Ecol., 15, 273-289.

Marsh-Matthews E. and Matthews W.J., 2000. Geographic, terrestrial and aquatic factors: which most influence the structure of stream fish assemblages in the Midwestern United States? Ecol. Freshwater Fish, 9, 9-21.

Matono P., 2012. Fish Assemblages as biological indicators in Portuguese rivers, Ph.D. thesis, University of Évora.

Mesquita N. and Coelho F., 2002. The ichthyofauna of the small Mediterranean-type drainages of Portugal: its importance for conservation. In: Collares-Pereira M.J., Cowx I.G. and Coelho F. (eds.), Conservation of freshwater fish: options for the future, Fishing News Books/Blackwell Science, Oxford, UK, 65-71.

Mesquita N.M., Coelho M. and Magalhães M.F., 2006. Spatial variation in fish assemblages across small Mediterranean drainages: effects of habitat and landscape context. Environ. Biol. Fish., 77, 105-120.

Monaghan K.A., Fonseca M.M., Domingues I. and Soares A.M.V.M., 2008. The effects of small scale impoundments and bank reinforcing on fish habitat and composition in semi natural streams. Pol. J. Ecol., 56, 647-657.

Nijboer R.C., Johnson R.K., Verdonschot P.F.M., Sommerhäuser M. and Buffagni A., 2004. Establishing reference conditions for European streams. Hydrobiologia, 516, 91-105.

Oberdorff T., Guegan J.F. and Hugueny B., 1995. Global scale patterns of fish species richness in rivers. Ecography, 18, 345-352.

Olden J.D. and Poff N.L., 2003. Toward a mechanistic understanding and prediction of biotic homogenization. Am. Nat., 162, 442-460.

Pires A.M., Cowx I.G. and Coelho M.M., 1999. Seasonal changes in fish community structure of intermittent streams in the middle reaches of the Guadiana basin, Portugal. J. Fish Biol., 54, 235-249.

Pires A.M., da Costa L.M., Alves M.J. and Coelho M.M., 2004. Fish assemblage structure across the Arade basin (Southern Portugal). Cybium, 28, 357-365.

Poff N.L., 1997. Landscape filters and species traits: towards mechanistic understanding and prediction in stream ecology. J. North Am. Benthol. Soc., 16, 391-409.

Pont D., Belliard T., Boet P., Changeux T., Oberdorff T. and Ombredane D., 1995. Analyse de la richesse piscicole de quatre ensembles hydrographiques Français. Bull. Fr. Pêche Piscic., 337-339, 75-81. 
Pont D., Hugueny B., Beier U., Goffaux D., Melcher A., Noble R., Rogers C., Roset N. and Schmutz S., 2006. Assessing river biotic condition at a continental scale: a European approach using functional metrics and fish assemblages. J. Appl. Ecol., 43, 70-80.

Pont D., Hugueny B. and Rogers C., 2007. Development of a fish-based index for the assessment of river health in Europe: the European Fish Index. Fish. Manag. Ecol., 14, 427-439.

Rahel F.J., 2000. Homogenization of fish faunas across the United States. Science, 288, 854-856.

Reyjold Y., Hugueny B., Pont D., Bianco P.G., Beier U., Caiola N., Casals F., Cowx I., Economou A., Ferreira M.T., Haidvolg G., Noble R., de Sostoa A., Vigneron T. and Virbickas T., 2007. Patterns in species richness and endemism of European freshwater fish. Global Ecol. Biogeogr., 16, 65-75.

Ribeiro O., 2011. Portugal, o Mediterrâneo e o Atlântico, 9th edition, Letra Livre, Lisboa.

Ribeiro F., Collares-Pereira M.J. and Moyle P.B., 2009. Non-native fish in the fresh waters of Portugal, Azores and Madeira Islands: a growing threat to aquatic biodiversity. Fish. Manag. Ecol., 16, 255-264.

Ricklefs R.E., 2006. Evolutionary diversification and the origin of the diversity-environment relationship. Ecology, 87, S3-S13.

Ricklefs R.E. and Schluter D., 1993. Species diversity in ecological communities: historical and geographical perspectives, University of Chicago Press, Chicago, IL.

Ricotta C., Carranza M.L. and Avena G., 2002. Computing-diversity from species-area curves. Bas. Appl. Ecol., 3, 15-18.

Sabater F., Guasch H., Martí E., Armengol J. and Sabater S., 1995. The Ter: a Mediterranean river casestudy in Spain. In: Cushing C.E., Cummins K.W. and Minshall G.W. (eds.), River ecosystems of the world, Elsevier, Amsterdam, 419-438.

Saunders D.L., Meeuwig J.J. and Vincent A.C.J., 2002. Freshwater protected areas: strategies for conservation. Conserv. Biol., 16, 30-41.

Schinegger R., Trautwein C., Melcher A. and Schmutz S., 2011. Multiple human pressures and their spatial patterns in European running waters. Water Environ. J., 26, 261-273.

Schlosser I.J., 1991. Stream fish ecology: A landscape perspective. BioScience, 41, 704-712.

Simberloff D. and Dayan T., 1991. The guild concept and the structure of ecological communities. Annu. Rev. Ecol. Syst., 22, 115-143.

Smith A.S. and Bermingham E., 2005. The biogeography of lower Mesoamerican freshwater fishes. J. Biogeogr., 32, 1835-1854.

Smith K.G. and Darwall W.R.T., 2006. The status and distribution of freshwater fish endemic to the Mediterranean basin, IUCN, Gland, Switzerland and Cambridge.

SNIRH, Sistema Nacional de Informação de Recursos Hídricos, http://snirh.pt. Accessed 27 July 2011. Southwood T.R.E., 1977. Habitat, the templet for ecological strategies? J. Anim. Ecol., 46, 337-365.

Sweeting R., 2001. Classification of ecological status of lakes and rivers: biological elements in the classification. In: Back S. and Karttunen K. (eds.), Classification of Ecological Status of Lakes and Rivers, TemaNord 2001: 584, Nordic Council of Ministers, Copenhagen.

Vannote R.L., Minshall G.W., Cummins K.W., Sedell J.R. and Cushing C.E., 1980. The river continuum concept. Can. J. Fish. Aquat. Sci., 37, 130-137.

Vila-Gispert A., García-Berthou E. and Moreno-Amich R., 2002. Aquat. Sci., 64, 163-170.

Whittaker R.J., Willis K.J. and Field R., 2001. Scale and species richness: towards a general, hierarchical theory of species diversity. J. Biogeogr., 28, 453-470.

Williams L.R., Taylor C.M., Warren M.L. and Clingenpeel J.A., 2003. Environmental variability, historical contingency and the structure of regional fish and macroinvertebrate fauna in Ouachita Mountain stream systems. Environ. Biol. Fish., 67, 203-216. 


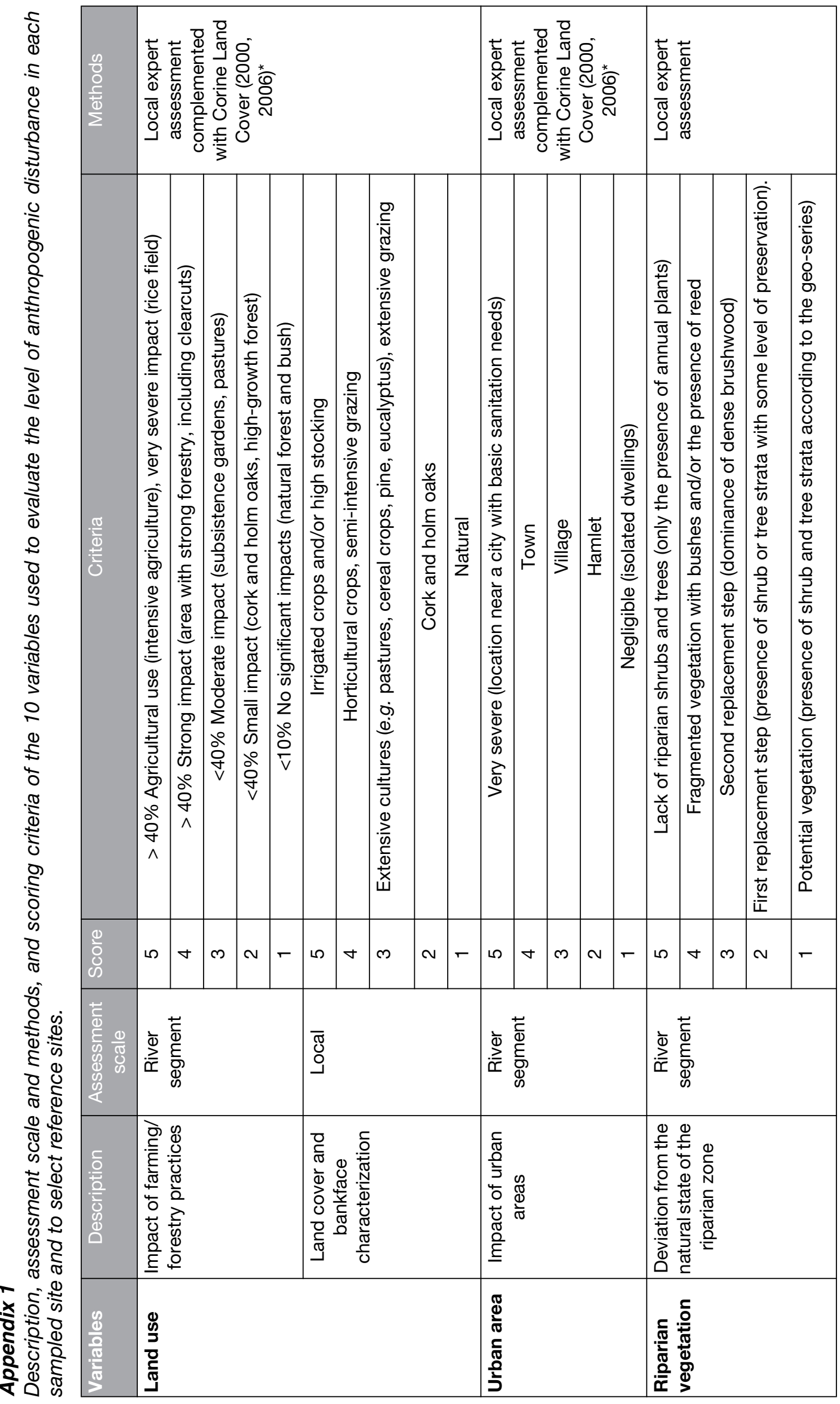




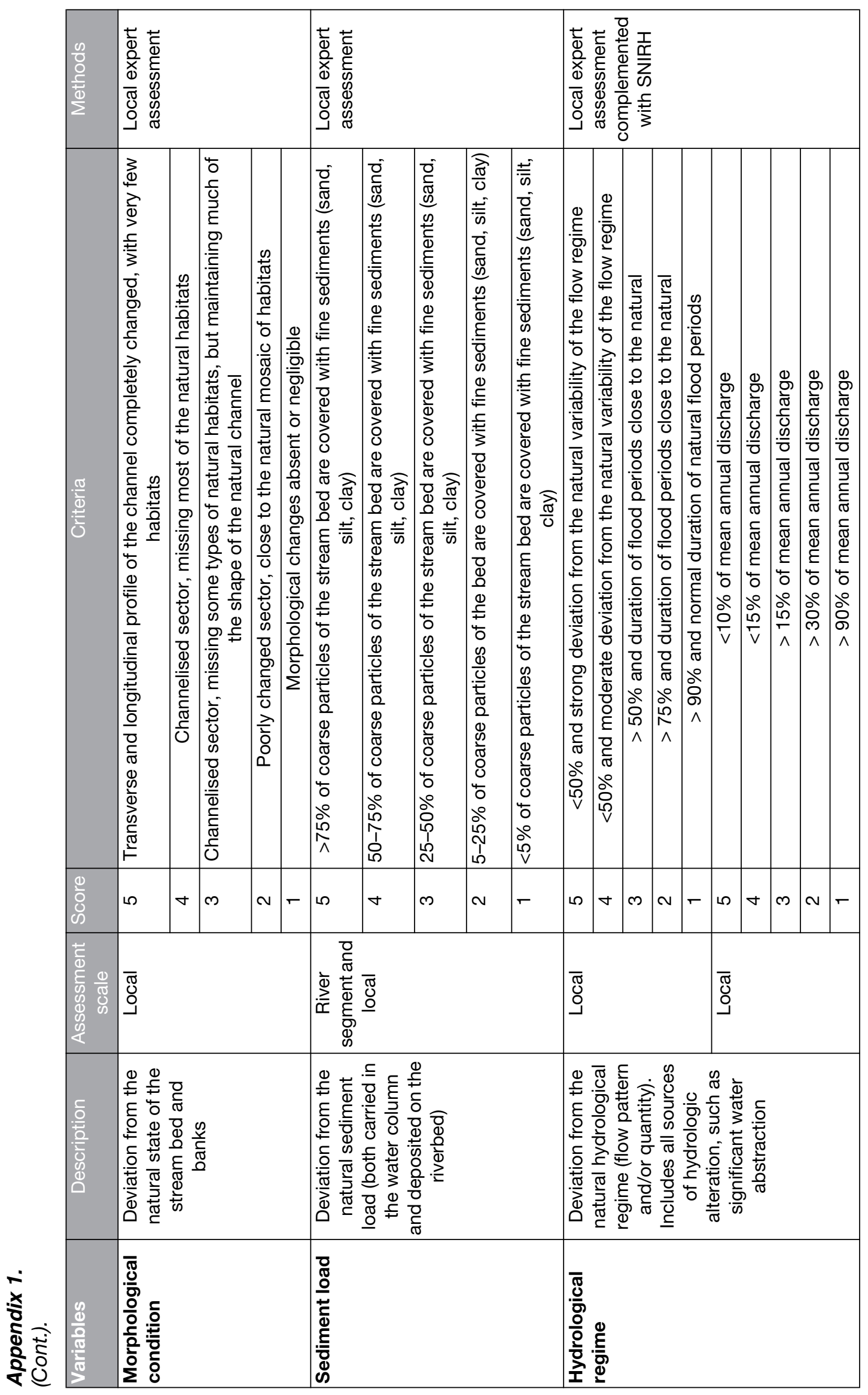




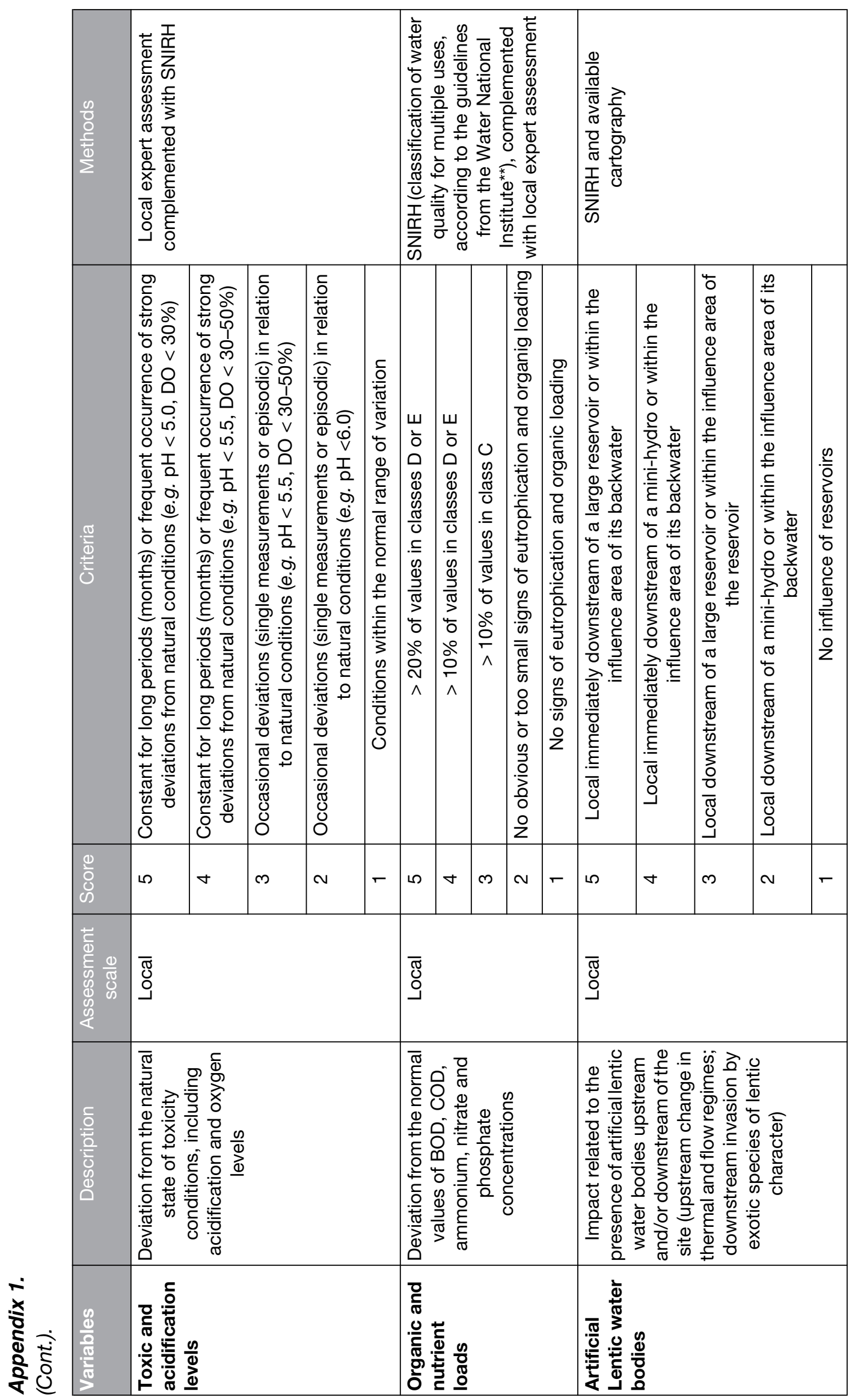




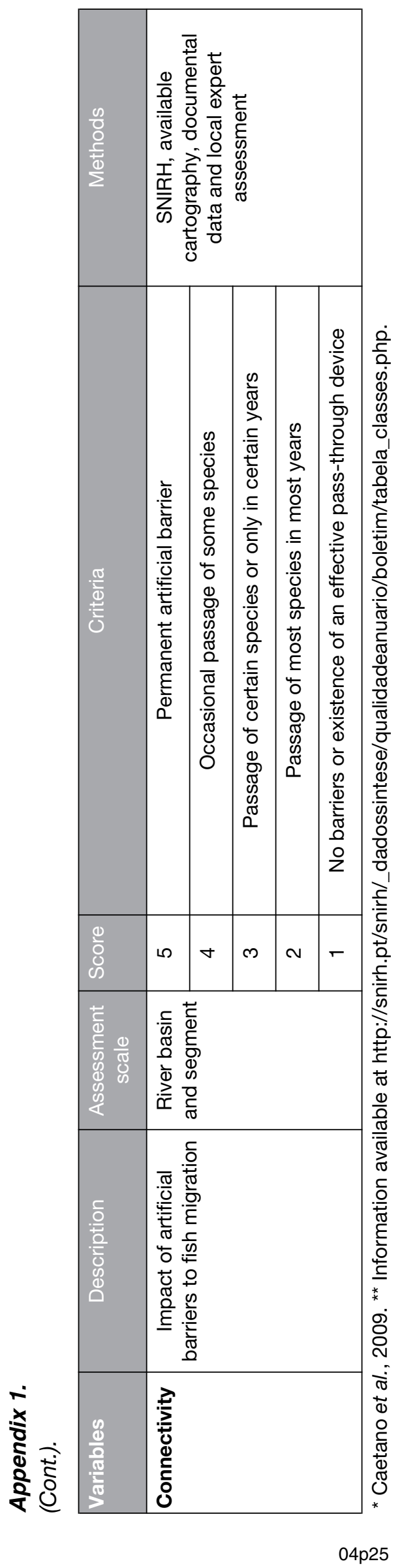

